PURBAWIDYA: Jurnal Penelitian dan Pengembangan Arkeologi p-ISSN: 2252-3758, e-ISSN: 2528-3618 Akreditasi LIPI No. 695/Akred/ P2MI-LIPI/07/2015 Vol. 8 (1), Juni 2019, pp 1 - 13 DOI: https://doi.org/10.24164/pw.v8i1.294

\title{
PERISTILAHAN KEKERABATAN SUNDA KUNO DAN REKONSTRUKSI ETNOARKEOLOGI HUKUM KELUARGA MASYARAKAT SUNDA KUNO
}

\section{Old Sundanese Kinship Terminology and Ethnoarchaeological Reconstruction of Family Law in Old Sundanese Society}

\author{
Dede Mulyanto ${ }^{1}$, Hazar Kusmayanti ${ }^{2}$ \\ ${ }^{1)}$ Departemen Antropologi, Universitas Padjadjaran \\ Jalan Raya Bandung--Sumedang Km 21 Jatinangor, Sumedang, Jawa Barat 45363 \\ E-mail: dede.mulyanto@unpad.ac.id \\ ${ }^{2)}$ Departemen Hukum Perdata, Universitas Padjadjaran \\ Jalan Raya Bandung--Sumedang Km 21 Jatinangor, Sumedang, Jawa Barat \\ E-mail: hazar.kusmayanti@unpad.ac.id
}

Naskah diterima 19 April 2019 - Revisi terakhir 19 Mei 2019

Disetujui terbit 27 Mei 2019 - Tersedia secara online 30 Juni 2019

\begin{abstract}
The research underlying this paper aims to reconstruct Old Sundanese kinship terminology and its consequences on the family law of the Old Sundanese community. Genealogical method was used to found kin terms and to reconstruct its structural features. From four manuscripts that have been studied, there were 25 term of refferences for 17 kin categories. Basically, old Sundanese kinship terminology have strong characteristics toward lineal-Eskimo type of terminology in which term of refferences for kins in nuclear family circle more descriptive and more classificatorist for other kins outside it. Balance distributions on kolateral kins also important in this type. Compared with contemporary Sundanese, there are no structural changes in Sundanese kinship terminology. Theoritically, the consequence of bilaterality in kinship terminology is parental nature of its family law. Probably, old Sundanese society also parental in their family law.
\end{abstract}

Keywords: kinship terminology, Old Sundanese, lineal-Eskimo, bilateral, ethnoarchaeology

\begin{abstract}
Abstrak
Penelitian yang mendasari tulisan ini bertujuan merekonstruksi sistem peristilahan kekerabatan Sunda Kuno dan konsekuensi sistem tersebut terhadap hukum keluarga masyarakat Sunda Kuno. Metode genealogi digunakan untuk menelusuri istilah kekerabatan dan merekonstruksi strukturnya. Berdasarkan empat naskah yang diteliti, terdapat 25 istilah sebutan kerabat untuk 17 kategori kerabat. Pada dasarnya, sistem peristilahan kekerabatan Sunda Kuno bertipe lineal-Eskimo yang deskriptif terhadap kerabat-kerabat di lingkaran keluarga batih, klasifikatoris terhadap kerabat-kerabat di luar keluarga batih, dan distribusi seimbang sebutan untuk kerabat-kerabat patrilateral ataupun matrilateral. Jika dibandingkan dengan kekerabatan Sunda kontemporer, secara struktural tidak ada perubahan. Konsekuensi bilateralitas dalam sistem peristilahan ini
\end{abstract}


ialah watak parental dari sistem hukum keluarganya. Besar kemungkinan masyarakat Sunda Kuno juga menganut hukum keluarga parental.

Kata kunci: peristilahan kekerabatan, Sunda Kuno, lineal-Eskimo, bilateral, etnoarkeologi

\section{PENDAHULUAN}

Jika dibandingkan dengan Majapahit atau Mataram, pemerian tentang Kerajaan Sunda terbilang tidak banyak. Lebih langka lagi ialah gambaran tentang kehidupan masyarakat Sunda. Kelangkaan ini terkait dengan fakta bahwa rekaman historis dari dalam peradaban Sunda Kuno sendiri termasuk langka sehingga rekonstruksinya nyaris mustahil.

Secara teoretis, terdapat dua jenis rekaman historis yang dapat digunakan sebagai sumber untuk merekonstruksi bagaimana masyarakat Sunda Kuno terorganisasi, yaitu prasasti dan naskahnaskah kuno (Nastiti, 2011). Hingga saat ini sudah ditemukan empat belas prasasti. Tiga di antaranya ditulis dengan aksara Kawi dan sebelas di antaranya ditulis dalam aksara Sunda Kuno (Nastiti \& Widyastuti, 2012); (Nastiti \& Djafar, 2016). Meskipun sebagian besar sudah dialih aksara dan dialihbahasakan, tidak satu pun prasasti yang mencatat tentang kehidupan masyarakat biasa. Sebagian besar hanya mencatat kenaikan tahta raja, peringatan pembuatan parit, penentuan daerah perdikan (sima), dan perbuatan yang terkait dengan raja-raja lainnya (Nastiti \& Djafar, 2016).

Langkanya gambaran kehidupan masyarakat di dalam prasasti dan naskahnaskah kuno mungkin merupakan alasan pokok mengapa kajian-kajian tentang Sunda Kuno masih berkutat dengan aspek filologis dari bahasa ini. Di dalam salah satu tulisannya, Nastiti mencoba merekonstruksi apa yang disebutnya masyarakat Sunda Kuno (Nastiti, 2006). Selain simpulan bahwa masyarakat Sunda Kuno pada dasarnya masyarakat yang ditopang oleh cara produksi perladangan, belum ada gambaran tentang bagaimana masyarakat ini terorganisasi melalui hubungan-hubungan keturunan dan perkawinan atau apa yang dikenal di dalam antropologi sebagai kekerabatan.

Kekerabatan merupakan salah satu pranata pengorganisasian sosial yang universal. Sudah sering dikatakan bahwa sistem kekerabatan Sunda itu bilateral atau parental. Namun, berkenaan dengan bagaimanakah sistem ini beroperasi secara aktual, belum banyak kajian yang dilakukan. Hingga saat ini baru ada tiga kajian tentang kekerabatan Sunda (Surjaman, 1960; Berthe, 1965; Horikoshi, 1976). Apabila hendak menelusuri sejak kapan bilateralitas menjadi ciri dari sistem kekerabatan Sunda atau bagaimanakah transformasinya di dalam lintasan masa, duduk perkaranya menjadi makin rumit karena sampai saat ini belum pernah ada kajian tentang kekerabatan Sunda Kuno. Dengan mempertimbangkan fakta belum adanya kajian kekerabatan Sunda Kuno, tulisan ini mengisi kekosongan tersebut dengan studi permulaan tentang salah satu aspek dari kekerabatan Sunda kuno tersebut, yakni sistem peristilahannya.

Tulisan ini didasarkan kepada penelusuran terhadap keteranganketerangan yang tersebar di empat naskah berbahasa Sunda Kuno, yaitu Sanghyang 
Siksakanda ng Karesian atau tercatat sebagai Kropak 630 di Perpustakaan Nasional (selanjutnya ditulis SSK-630), Darmajati atau Kropak 423 (selanjutnya ditulis D-423), Amanat Galunggung atau Kropak 632 (selanjutnya ditulis AG-632), dan Carita Parahyangan atau Kropak 406 (selanjutnya ditulis CP-406). Keempatnya sudah dipastikan berasal dari masa praIslam.

Keempat naskah kuno ini telah dialih aksara, dialih bahasa, dan disunting oleh para ahli filologi. Filolog awal untuk SSK630 ialah Atja (Atja, 1981). Pembaruannya dimuat di dalam Danasasmita dkk. (Danasasmita, S., Ayatrohaedi, Wartini, T., Darsa, 1987) dan edisi cetakan mutakhirnya ialah Abdurrahman (Abdurrahman, 2015). Terbitan D-423 yang dirujuk di dalam tulisan ini ialah karya Darsa, Ekadjati, dan Ruhimat (Darsa, Ekadjati, \& Ruhimat, 2004). Terbitan AG-632 yang dirujuk di sini ialah Atja dan Danasasmita (Atja \& Danasasmita, 1981a), sementara terbitan CP-406 yang dirujuk ialah Atja dan Danasasmita (Atja \& Danasasmita, 1981b).

Banyaknya kosakata dalam Bahasa Sunda Kuno dipinjam atau dipengaruhi oleh Bahasa Kawi yang pada gilirannya juga berakar pada bahasa Sanskerta, sebagai bahan pembanding, penulis juga meninjau Kamus Jawa Kuna (Zoetmulder, 1995) dan Kamus Bahasa Naskah dan Prasasti Sunda Abad ke-11 s.d. ke-18 (Suryani, 2001) untuk mempertegas arti kata tertentu.

Terkait istilah-istilah kekerabatan Sunda masa kini yang dijadikan perbandingan, penulis merujuk kepada Surjaman dan Horikoshi untuk kekerabatan Sunda di Priangan (Surjaman, 1960; Horikoshi, 1976), serta kepada Berthe,
Garna, dan Iskandar untuk istilah-istilah kekerabatan Sunda Baduy (Berthe, 1965; Garna, 1987; Iskandar, 1998).

Secara teknis, untuk memudahkan pemerian, di dalam studi-studi kekerabatan diciptakan kode-kode berbasis huruf-huruf aksara Latin sebagai rujukan formal untuk kategori kerabat inti (Schusky, 1965; Braun, 1988). Di dalam tulisan ini, kodekode beserta artinya ialah sebagai berikut.

\begin{tabular}{|c|c|c|c|}
\hline Kode & $\underset{\text { Formal }}{R \text { u u k a n }}$ & Kode & $\underset{\text { Formal }}{R \text { u j u k a n }}$ \\
\hline $\mathrm{F}$ & $\begin{array}{l}\text { Orang tua } \\
\text { laki-laki }\end{array}$ & St & Kerabat tiri \\
\hline M & $\begin{array}{l}\text { Orang tua } \\
\text { perempuan }\end{array}$ & $\mathrm{P}$ & Orang tua \\
\hline $\mathrm{S}$ & $\begin{array}{l}\text { Keturunan } \\
\text { langsung laki- } \\
\text { laki }\end{array}$ & $\mathrm{C}$ & $\begin{array}{l}\text { Keturunan } \\
\text { langsung }\end{array}$ \\
\hline $\mathrm{D}$ & $\begin{array}{l}\text { Keturunan } \\
\text { langsung } \\
\text { perempuan }\end{array}$ & Sib & $\begin{array}{l}\text { Saudara } \\
\text { kandung }\end{array}$ \\
\hline B & $\begin{array}{l}\text { Saudara } \\
\text { kandung laki- } \\
\text { laki }\end{array}$ & $\mathrm{y}$ & $\begin{array}{l}\text { Yang lebih } \\
\text { muda }\end{array}$ \\
\hline Z & $\begin{array}{l}\text { Saudara } \\
\text { kandung } \\
\text { perempuan }\end{array}$ & e & $\begin{array}{l}\text { Yang lebih } \\
\text { tua }\end{array}$ \\
\hline $\mathrm{H}$ & Suami & G & Generasi \\
\hline W & Istri & +1 & $\begin{array}{l}\text { Setingkat di } \\
\text { atas ego }\end{array}$ \\
\hline \multirow[t]{2}{*}{$\mathrm{Co}$} & $\begin{array}{l}\text { Pasangan } \\
\text { kawin }\end{array}$ & -1 & $\begin{array}{l}\text { Setingkat di } \\
\text { bawah ego }\end{array}$ \\
\hline & & 0 & $\begin{array}{l}\text { Setingkat } \\
\text { dengan ego }\end{array}$ \\
\hline
\end{tabular}

Cara kerja penelitian ialah sebagai berikut. Pertama-tama, penulis mencari dan mengumpulkan istilah-istilah sebutan kekerabatan di dalam keempat naskah sumber. Setelah terkumpul, istilah-istilah tersebut dicari rujukan pengertiannya dengan membandingkan hasil alih bahasa oleh para penyunting naskah dengan 
pengertian kata temuan, seperti tercantum di dalam kamus-kamus rujukan. Setelah itu, istilah-istilah tersebut disulih ke dalam kode-kode formal, kemudian ditata ke dalam susunan korelasional.

\section{HASIL DAN PEMBAHASAN}

\section{Sistem Peristilahan Kekerabatan Sunda Kuno}

Di bagian ini dipaparkan hasil rekonstruksi terhadap sistem peristilahan kekerabatan Sunda Kuno. Rekonstruksi ini didasarkan kepada 25 istilah sebutan kerabat yang mengisi 17 kategori kerabat yang ditemukan di dalam keempat naskah yang diteliti. Rekonstruksi meliputi istilah-istilah sebutan kekerabatan dan pengertiannya, tipe sistem peristilahan, dan asas-asas klasifikasi kerabat. Perbandingan juga dilakukan dengan sistem peristilahan kekerabatan Sunda kontemporer untuk mengetahui ada atau tidaknya perubahan struktural di dalam sistem peristilahan Sunda secara umum.

\section{- Istilah-Istilah Kekerabatan}

Di dalam masyarakat Sunda kontemporer $^{1}$, semua orang yang masih mempunyai pertalian kekerabatan disebut baraya. Istilah ini ditemukan di dua naskah, yakni CP-406 dan SSK-630. Pada dua naskah tersebut, di samping baraya dipakai juga istilah kulakadang (CP-406)

1 Yang dimaksud ialah masyarakat penutur bahasa Sunda pascakemerdekaan, termasuk masyarakat Baduy, yang sistem kekerabatan sudah pernah diteliti oleh Surjaman (1960), Berthe (1965), Horikoshi (1976), Garna (1987), dan Iskandar (1998). Di dalam tulisan ini setiap pernyataan tentang kekerabatan yang mengandung masyarakat Sunda kontemporer merujuk pada temuan lima penelitian tersebut. dan kadang (SSK-630), dua istilah yang tidak dikenal lagi dalam bahasa Sunda yang dipakai saat ini. Dari konteksnya, dua istilah terakhir agak dekat dengan definisi baraya, yakni semua orang yang masih mempunyai pertalian kekerabatan dengan ego. Namun, berlainan dengan konteks sosial, baraya, kulakadang, atau kadang mempunyai kecenderungan lebih sempit artinya dengan rujukan kepada semua kerabat di lingkaran terdekat ego saja, yakni orang tua dan saudara kandung. Mungkin padanan saat ini dari kulakadang atau kadang ialah dulur.

Di dalam masyarakat Sunda kontemporer, semua orang yang dianggap tidak memiliki pertalian kekerabatan dengan ego disebut deungeun-deungeun. Istilah deungeun (tanpa pengulangan) ditemukan di dalam dua naskah, yakni CP406 dan D-423, dengan pengertian yang relatif sama. Pada dasarnya masyarakat Sunda tidak mengenal kelompok seketurunan seperti masyarakat Batak atau Minangkabau, sehingga batas-batas antara baraya dan deungeun tidak begitu jelas.

Terdapat tiga hubungan kekerabatan fundamental universal, yakni peranakan (orang tua-anak, P-C), perkawinan (suamiistri, $\mathrm{H}-\mathrm{W})$, dan persaudaraan (B-Z). Di dalam hubungan peranakan, orang tua (P) secara kolektif disebut kolot, kokolot, atau buayah (singkatan dari ambu-ayah). Berdasarkan jenis kelamin, orang tua lakilaki dibedakan sebutannya dari sebutan untuk orang tua perempuan. Di dalam tiga naskah, yakni AG-632, CP-406, dan SSK630, orang tua laki-laki (F) disebut bapa, sedangkan di dalam D-423 orang tua lakilaki disebut ayah. Di dalam dua naskah, yakni CP-406 dan D-423, orang tua perempuan (M) hanya disebut ambu. Di dalam SSK-630, kategori ini disebut ambu 
dan juga indung. Di dalam AG-632 hanya disebut indung. Kecuali ayah yang tidak lagi lazim dipakai untuk merujuk orang tua laki-laki, semua sebutan untuk orang tua pada keempat naskah tersebut masih dipakai atau dikenali oleh orang Sunda saat ini. Sebutan ayah masih dipakai oleh orang Baduy untuk merujuk orang tua laki-laki (Berthe, 1965).

Kategori untuk kerabat lineal ${ }^{2}$ lainnya, selain orang tua, ialah orang tuanya orang tua. Pada keempat naskah hanya ditemukan sebutan untuk orang tua lakilakinya orang tua (PF), yakni aki. Di dalam SSK-630, selain aki, juga disebut kaki dengan rujukan kepada kategori yang sama. Untuk kerabat lineal di bawah ego, semua naskah menggunakan istilah anak untuk semua keturunan langsung ego. Pada tingkatan generasi yang lebih bawah lagi, hanya dua naskah, yakni AG-632 dan CP-406, yang menyebutkan satu kategori. Di dalam AG-632 anaknya anak (CC) disebut euncu, sedangkan di dalam CP406 disebut putu.

Selain kerabat lineal di atas, istilah untuk kerabat konsanguinal ${ }^{3}$ lain yang terdapat di dalam naskah ialah sebutan untuk saudara kandung (Sib). Di dalam CP-406 dan SSK-630, semua orang yang diperanakkan oleh orang tua yang sama disebut adilanceuk, sedangkan di dalam AG-632 disebut sapilanceuk. Di dalam CP-406 dan SSK-630, saudara kandung dibedakan berdasarkan asas anterioritas kelahirannya, yakni lanceuk untuk yang

2 Kerabat-kerabat sedarah yang terhubungan dengan ego secara langsung melalui hubungan keturunan atau peranakan, baik itu ke atas maupun ke bawah.

3 Kerabat-kerabat yang mempunyai pertalian darah. lebih tua (eSib) dan adi untuk yang lebih muda (ySib). Hanya SSK630 yang menyebutkan istilah kakang dengan rujukan khusus kepada saudara laki-laki lebih tua dan euceu dengan rujukan kepada saudara perempuan lebih tua. Penerapan asas anterioritas kelahiran, baik dengan imbuhan asas pembedaan jenis kelamin maupun tidak, ini lazim di dalam sistem peristilahan kekerabatan bahasa-bahasa Austronesia.

Berdasarkan uraian pada keempat naskah, hanya SSK-630 yang menyebutkan istilah suan dan kaponakan. Tidak begitu tegas kepada siapakah kategori ini merujuk. Istilah kaponakan tidak dikenal dalam peristilahan kekerabatan Sunda kontemporer. Namun, apabila kita bandingkan dengan istilah ponakan yang terdapat di dalam peristilahan kekerabatan Jawa (Robson, 1987), mungkin yang dimaksud kaponakan ialah anak saudara kandung ego (SibC). Sementara itu, di dalam bahasa Sunda masa kini, istilah suan masih dikenal dengan rujukan kepada semua anak saudara kandung lebih tuanya ego (eSibC) dan biasanya istilah sebutan ini dikontraskan dengan istilah alo, yaitu anak dari saudara kandung yang lebih mudanya ego (ySibC). Apabila konteks penyebutan istilah suan dan kaponakan dalam SSK-630 dicermati, kemungkinan besar yang dimaksud kaponakan saat itu sama artinya dengan istilah sebutan alo dalam peristilahan Sunda kontemporer.

Hanya SSK-630 yang menyebutkan istilah kapi adi dan kapi lanceuk. Tidak begitu terang siapa kerabat yang dirujuk kedua istilah sebutan tersebut. Di dalam masyarakat Sunda kontemporer, kedua istilah tersebut masih dikenal dengan rujukan kepada semua kerabat yang segenerasi dengan ego di luar saudara 
kandung meskipun dapat diperlakukan dan dipanggil seperti halnya memperlakukan dan memanggil saudara kandung. Kata kunci kedua istilah tersebut ialah kata kapi yang dapat diartikan 'sebagai' seperti kerabat tertentu meskipun bukan kerabat.

Hanya ada dua kategori dari tiga kerabat afinal $^{4}$ yang disebutkan dalam keempat naskah, yaitu rujukan kepada suami dan istri. Dalam tiga naskah, yaitu AG-632, CP-406, dan SSK-630, kategori istri (W) disebut ewe, sedangkan dalam D-423 kategori istri disebut dengan istilah rabi. Dalam CP-406, sebutan untuk suami (H) ialah salaki, sementara di dalam SSK630 suami disebut laki dan juga salaki.

Selain pasangan kawin (Co), di dalam salah satu naskah, yakni CP-406, juga terdapat sebutan untuk kerabat afinal lain, yakni ambu tere. Istilah tere lazim dipakai di dalam peristilahan kekerabatan Sunda kontemporer sebagai imbuhan pada salah satu sebutan untuk anggota keluarga batih ego. Tere merujuk kepada orang yang terhubungan dengan ego melalui perkawinan salah satu orang tuanya yang telah bercerai dengan orang lain, misalnya di dalam CP-406 ambu tere berarti perempuan yang menikahi orang tua laki-lakinya ego. Tere adalah istilah klasifikatoris atau relasional yang hanya bermakna sebagai imbuhan untuk sebutan intinya. Dalam kasus CP-406, tere ialah imbuhan pada ambu. Orang yang tergolong sebagai ambu tere bukanlah $a m b u$ sebenarnya dari ego, tetapi secara struktural berkedudukan seperti halnya ambu karena kedudukannya sebagai istri orang tua laki-laki ego.

4 Kerabat yang terhubung dengan ego melalui perkawinan.

\section{- Tipe Peristilahan Kekerabatan}

Berdasarkan keterangan yang sangat terbatas di atas, kita dapat merekonstruksi tipe sistem peristilahan kekerabatan yang dianut masyarakat Sunda Kuno sebagai berikut.

Dengan absennya istilah-istilah untuk kerabat-kerabat kolateral orang tua, yakni saudara kandung orang tua, kita tidak dapat menentukan apakah tipe peristilahan kekerabatan Sunda Kuno itu lineal atau generasional, bertipe Eskimo ataukah Hawaiian. Di dalam tipe lineal atau Eskimo, biasanya sebutan untuk orang tua dibedakan dari sebutan untuk saudara kandung orang tua dengan distribusi seimbang penyebutan saudara kandung orang tua, baik dari garis ayah (patrilateral) maupun dari garis ibu (matrilateral). Sementara itu, di dalam tipe generasional atau Hawaiian, sebutan untuk orang tua disamakan dengan sebutan untuk saudara kandung orang tua. Jadi, secara teoretis setidaknya akan ada empat istilah kekerabatan di tingkat generasi orang tua $(\mathrm{G}+1)$ pada tipe lineal atau Eskimo dan hanya dua pada tipe generasional atau Hawaiian (Lowie, 1928: 141 - 142; Murdock, 1949: 223 - 224).

Sebagai contoh, bentuk klasik tipe lineal ialah peristilahan kekerabatan Nunamiut, salah satu suku Eskimo di Kanada. Di dalam peristilahan kekerabatan Nunamiut, sebutan untuk orang tua lakilaki (F) ialah apa dan untuk orang tua perempuan (M) ialah aaka. Sementara itu, untuk saudara kandung orang tua (PSib) berturut-turut ialah angaluk untuk saudara laki-laki dan atcak untuk saudara perempuan. Di dalam sistem kekerabatan Nunamiut, sebutan angaluk berlaku, baik untuk saudara laki-laki ayah (FB) maupun saudara laki-laki ibu (MB). Begitu 
pula dengan sebutan atcak (Pospisil \& Laughlin, 1963).

Contoh bentuk klasik tipe generasional ialah peristilahan kekerabatan Hawaii. Di dalam peristilahan kekerabatan Hawaii, makuakane, sebutan untuk orang tua laki-laki (F), berlaku juga untuk saudara laki-laki ayah (FB) dan ibu (MB). Begitu pula sebutan makauahine untuk orang tua perempuan ego (M), berlaku juga untuk saudara perempuan ayah (FZ) dan ibu (MZ) (Handy \& Pukui, 1951).

Turun ke sebutan-sebutan kerabat pada generasi ego (G0) juga tidak ada keterangan lebih lengkap untuk mengetahui tipe peristilahan apa yang dianut masyarakat Sunda Kuno. Pada G0, hanya terdapat pemilahan antara saudara kandung dan bukan-saudara kandung. Di antara saudara kandung (Sib), ada pemilahan antara saudara laki-laki, yakni kakang, dan saudara perempuan, yakni euceu. Namun, kedua sebutan ini mempunyai arti khusus karena diimbuhi arti 'yang lebih tua'. Secara formal, kakang berarti saudara laki-laki lebih tua (eB) dan eисеu berarti saudara perempuan lebih tua (eZ). Untuk saudara lebih muda, hanya ada satu istilah sebutan, yakni adi. Secara formal adi berarti semua saudara kandung yang lebih muda (eSib), tidak memandang jenis kelaminnya.

Pada generasi setingkat di bawah ego (G-1), ciri lineal kekerabatan Sunda Kuno lebih menonjol. Di dalam bentuk klasik tipe lineal, sebutan untuk keturunan langsung ego dibedakan dari sebutan untuk keturunan langsung kerabat kolateral ego. Pada peristilahan kekerabatan Sunda Kuno, keturunan langsung ego dikategorikan sebagai anak, sementara untuk keturunan langsung kerabat kolateral ego terdapat dua istilah sebutan berbeda, yakni suan dan kaponakan. Istilah anak bersifat nir-gender. Apabila asas pemilahan berdasarkan jenis kelamin diterapkan, istilah anak diimbuhi dengan istilah rujukan jenis kelamin. Di dalam SSK-630 dibedakan antara anak wadon dan anak lanang. Kemungkinan besar anak wadon merujuk pada keturunan langsung perempuan (D), sementara anak lanang merujuk pada keturunan langsung laki-laki ego (S).

Seperti halnya pada sebutan anak, tampaknya istilah suan dan kaponakan juga tidak bergender. Selain itu, suan dan kaponakan juga tampaknya tidak dibedakan, apakah patrilateral (kerabat dari pihak orang tua laki-laki) atau matrilateral (kerabat dari pihak orang tua perempuan). Distribusi seimbang pada kerabat lateral ini juga menjadi ciri klasik dari tipe lineal-Eskimo.

\section{- Asas Klasifikasi Kekerabatan}

Beralih ke kaidah klasifikasi, tampaknya jenis kelamin dan generasi merupakan asas pokok pada kekerabatan Sunda Kuno. Pada garis lineal terdapat kategori kolot-anak-incu, tiga istilah sebutan klasifikatoris berbasis generasi. Pada $\mathrm{G}+1$, sebutan untuk orang tua dibedakan antara yang laki-laki (bapa, ayah) dan yang perempuan (ambu, indung). Begitu pula pada G0 yang membedakan saudara laki-laki (kakang) dan saudara perempuan (euceu). Namun, pada G0 ini juga terdapat asas lain yang tidak ditemukan di dalam sistem peristilahan kekerabatan yang berciri lineal dari bangsa-bangsa Eropa, tetapi lazim berlaku pada bangsabangsa Austronesia, misalnya, yakni asas anterioritas. Semua saudara kandung yang umurnya lebih muda, tidak pandang jenis kelaminnya, disebut adi. Pembedaan 
jenis kelamin hanya berlaku pada saudara kandung yang lebih tua.

Dengan absennya istilah-istilah kekerabatan untuk kerabat kolateral $\mathrm{G}+1$, yaitu saudara kandung orang tua, kita belum dapat secara tegas menentukan apakah asas anterioritas juga berlaku pada lapisan generasi ini. Satu-satunya keterangan untuk mengafirmasi simpulan tersebut ialah terdapatnya sebutan suan yang dibedakan dari kaponakan pada generasi G-1. Dengan asumsi kaponakan yang setara dengan ponakan dalam peristilahan kekerabatan Jawa (Robson, 1987) dan dengan alo, seperti yang masih dipakai oleh orang Sunda masa sekarang yang merujuk kepada keturunan langsung saudara yang lebih tua dari ego dan suan yang merujuk kepada keturunan langsung saudara yang lebih muda dari ego, seperti yang berlaku dalam peristilahan Sunda saat ini, dapat dipastikan ada pembedaan berdasarkan anterioritas untuk sebutan pada $\mathrm{G}+1$ karena rujukan dari kedua sebutan tersebut didasarkan pada urutan kelahiran orang tuanya yang relatif terhadap ego. Untuk lebih terang, secara formal, suan ialah anak dari saudara yang lebih muda (ySibC), sedangkan kaponakan ialah anak dari saudara lebih tua (eSibC).

Penerapan asas anterioritas ini berlaku pada banyak peristilahan kekerabatan bangsa-bangsa penutur bahasa Austronesian. Dalam peristilahan kekerabatan Jawa, misalnya, pada $\mathrm{G}+1$ terdapat istilah pakdhe $(\mathrm{PeB})$ dan budhe (PeZ) untuk saudara kandung yang lebih tua dari orang tua ego, serta paklik (PyB) dan bulik (PyZ) untuk menyebut saudara kandung yang lebih muda dari orang tua ego (Robson, 1987).

Dengan demikian, dapat disimpulkan bahwa pada dasarnya sistem peristilahan kekerabatan Sunda Kuno bertipe lineal atau Eskimo dengan asas pokok klasifikasi kerabatnya ialah pembedaan jenis kelamin, generasi, dan pemisahan antara kerabat konsanguinal di dalam keluarga batih serta kerabat kolateral. Seperti pada peristilahan kekerabatan bangsa-bangsa penutur bahasa Austronesia lainnya, anterioritas menjadi asas penting.

\section{- Perbandingan}

Cara mengetahui perubahan di dalam suatu sistem peristilahan kekerabatan ialah perbandingan lintas masa. Di bagian ini penulis membandingkan peristilahan kekerabatan Sunda Kuno dengan peristilahan kekerabatan Sunda modern. Dua sumber yang digunakan adalah kamus dwibahasa Sunda-Inggris susunan Johanthan Riggs (Riggs, 1862) dan artikel Louis Berthe (Berthe, 1965). Riggs, seorang anggota Perkumpulan untuk Seni dan Ilmu Batavia, menyusun kamus dwibahasa pertamanya itu dengan melakukan penelitian lapangan di Bogor dan wilayah sekitarnya.

\begin{tabular}{llll}
\hline Kode & Sunda Kuno & Riggs (1862) & Berthe (1965) \\
\hline PF & Aki, Kaki & Aki & Aki, Kai \\
PM & $(-)$ & Nini & Nini, Nyai \\
P & Kolot, Buayah & Kolot & Kolot \\
F & Bapa, Ayah & Bapa, Ama & Ayah, Bapa \\
M & Ambu, Indung & Ambu, Indung & Ambu \\
\hline
\end{tabular}




\begin{tabular}{llll}
\hline PeSib & $(-)$ & Uah & Ua \\
PyB & $(-)$ & Mamang, Paman & Mamang \\
PyZ & $(-)$ & Bibi & Bibi \\
Sib & Sapilanceuk, & Adilanceuk & Dulur \\
& Adilanceuk & & \\
eB & Kakang & Kakang, Kaka & Kaka \\
eZ & Euceu & Euceu, Teteh & Teteh \\
eSib & Lanceuk & Lancheuk & Lanceuk \\
ySib & Adi & Adi & Adi \\
PSibC & $(-)$ & Misan & Misan, Dulur Misan \\
C & Anak & Anak & Anak \\
S & Anak Lanang & Anak Lalaki & Anak Lalaki \\
D & Anak Wadon & Anak Wadon & Anak Awewe \\
eSibC & Kaponakan & Alo & Alo \\
ySibC & Suan & Suan & Suan \\
CC & Euncu, Putu, Incu & Inchu & Incu \\
H & Laki, Salaki & Laki, Salaki & Salaki \\
W & Ewe, Rabi & Ewe & Pamajikan, Awewe \\
\hline
\end{tabular}

Ket.: (-) tidak ada keterangan.

Keterangan tentang istilah-istilah kekerabatan untuk kerabat pada $\mathrm{G}+1$ lebih lengkap pada Riggs (Riggs, 1862) dan Berthe (Berthe, 1965), ciri lineal-Eskimo pada kekerabatan Sunda lebih jelas. Distribusi imbang sebutan pada kerabat kolateral orang tua ditegaskan bahwa $u a$ merujuk, baik kepada saudara orang tua laki-laki (FSib) maupun terhadap saudara yang lebih tua dari orang tua perempuan ego (MSib). Hal sama juga berlaku untuk mamang dan bibi. Pembedaan penyebutan untuk orang tua dan saudara kandungnya ini merupakan tanda tegas bahwa alih-alih generasional, kekerabatan Sunda bersifat bilateral. Bilateralitas yang dicirikan distribusi penyebutan yang sama untuk kerabat matrilateral dan patrilateral ini juga berlaku pada G-1.

Berdasarkan tujuh belas kategori sebutan kerabat yang dapat direkonstruksi dari naskah-naskah Sunda Kuno, sebelas sebutan di antaranya tidak mengalami perubahan kata jika dibandingkan dengan istilah sebutan modern. Hanya dua istilah sebutan yang kini tidak dikenal lagi, yakni sapilanceuk untuk merujuk saudara kandung (Sib) dan kaponakan untuk menyebut keturunan langsung saudara kandung ego (eSibC). Alih-alih sapilanceuk, orang Sunda sekarang lebih lazim menggunakan istilah dulur dan alihalih kaponakan saat ini istilah alo lebih lazim dipakai.

Sebutan untuk istri berubah. Jika pada masa Sunda Kuno dan abad ke-19, ewe lazim dipakai sebagai istilah rujukan, pada abad ke-20 istilah yang lazim ialah awewe atau pamajikan.

Berdasarkan perbandingan di atas, dapat disimpulkan, meskipun ada beberapa perubahan pilihan kata, pada dasarnya secara struktural tidak ada perubahan di dalam sistem peristilahan 
kekerabatan Sunda. Struktur yang berlaku pada masa Sunda Kuno tetap bertahan hingga saat ini.

\section{Rekonstruksi Etnoarkeologis Hukum Keluarga pada Masyarakat Sunda Kuno}

Catatan historis tentang bagaimana masyarakat Sunda Kuno yang terorganisasi di dalam kehidupan sehari-hari tidak dapat ditemukan di dalam prasasti-prasasti atau naskah-naskah kuno. Oleh karena itu, nyaris mustahil mengetahui satu aspek pengorganisasian sosial, misalnya hukum keluarga yang memengaruhi, cara bagaimana orang Sunda Kuno hidup sebagai komunitas dari sumber-sumber tersebut. Akan tetapi, ada cara lain untuk memperkirakannya. Salah satunya ialah melalui etnoarkeologi.

Etnoarkeologi ialah suatu pendekatan atau alat bantu metodologis yang berkembang di dalam disiplin arkeologi untuk menafsirkan temuan-temuan material dari masa silam yang konteks sosiokulturalnya sudah tidak ada lagi dengan membandingkan gambaran konteks sosiokultural masyarakat masa kini yang dianggap masih memiliki keterkaitan historis dengan masyarakat pengampu artefak yang hendak diteliti (London, 2000).

Secara teoretis, sistem peristilahan kekerabatan mencerminkan juga sistem pengorganisasian sosial dalam masyarakat yang menganutnya. Setidaknya, sistem peristilahan memantulkan gagasan suatu masyarakat tentang keterhubungan antarorang dengan moralitas tertentu yang menjalinkan keterhubungan tersebut (Robson, 1987; Geertz, 1989). Di bagian ini, penulis akan memakai etnoarkeologi untuk membantu memahami aspek legal sistem peristilahan kekerabatan Sunda Kuno, yaitu konsekuensinya terhadap hukum keluarga, dengan mencari dan membandingkan padanannya di dalam hukum keluarga pada masyarakat Sunda abad ke-20 (Soepomo, 1967).

Seperti sudah dipaparkan di bagian sebelumnya, secara struktural tidak ada perubahan di dalam sistem peristilahan kekerabatan Sunda. Ditambah dengan asumsi bahwa bilateralitas dalam sistem peristilahan kekerabatan berkorelasi dengan paternalitas di dalam hukum keluarga. Berikut beberapa kemungkinan hukum keluarga yang berlaku pada masyarakat Sunda Kuno.

Terkait sistem kekerabatannya secara umum, masyarakat Sunda Kuno kemungkinan memperhitungkan alur keturunan melalui garis ayah ataupun ibu secara seimbang. Konsekuensinya terhadap hukum keluarga ialah bahwa kedudukan suami-istri di dalam lembaga perkawinan setara derajatnya, baik itu secara perseorangan maupun dalam soal harta benda. Kedua orang tua juga mempunyai kuasa yang setara terhadap anak-anak dan apabila terjadi perceraian, kuasa itu dapat diserahkan, baik kepada orang tua laki-laki maupun orang tua perempuan (Soepomo, 1967: $1)$.

Namun, apabila dibandingkan temuan di lapangan tentang bagaimana sistem kekerabatan Sunda beroperasi saat ini, di dalam aspek lokalitas terdapat kecenderungan ke arah matrilokalitas (Horikoshi, 1976; Berthe, 1965) yaitu bahwa pasangan yang baru kawin tinggal bersama dengan orang tua pengantin perempuan, apakah hukum keluarga seperti ini juga berlaku pada masyarakat Sunda Kuno? 
Apabila dibandingkan dengan simpulan Nastiti (Nastiti, 2006) bahwa masyarakat Sunda Kuno pada dasarnya ialah masyarakat peladang dan secara ekologi kultural sistem perladangan itu mengisyaratkan sebentuk keluarga inti yang hanya terdiri atas ayah-ibu-anak yang belum dewasa yang tinggal bersama dengan berpindah dari satu ladang ke ladang baru berikutnya, ada kemungkinan alih-alih ke arah matrilokalitas, masyarakat Sunda Kuno secara teoretis condong kepada sistem neolokalitas, yang di situ pasangan kawin tinggal terpisah di tempat baru. Ada kemungkinan matrilokalitas seperti yang dianut masyarakat Sunda saat ini adalah warisan dari sedenterisasi, yaitu ketika mereka mengembangkan cara produksi pertanian menetap.

Aspek hukum keluarga lain yang dapat ditarik secara teoretis ialah kewajiban antara orang tua dan anak dalam hal nafkah. Menurut hukum adat Sunda saat ini, secara normatif di antara orang tua dan anak terdapat kewajiban saling memberikan nafkah (Soepomo, 1967: 5). Apabila orang tua bercerai, baik ayah maupun ibu secara normatif wajib memberikan sokongan nafkah anak. Tidak ada kewajiban lebih yang mesti ditanggung hanya oleh salah satu dari kedua orang tua (Soepomo, 1967: 7 - 8). Hukum ini secara teoretis berlaku pada masyarakat Sunda Kuno dengan pertimbangan ada kesamaan struktural antara sistem peristilahannya dengan sistem peristilahan Sunda modern yang juga berwatak bilateral.

Watak bilateralitas kekerabatan juga terkait dengan fakta bahwa hak mewaris anak-anak tidak dibedakan berdasarkan jenis kelamin. Pada masyarakat Sunda, hak ini berlaku sepenuhnya meskipun sudah menganut agama Islam yang cenderung patrilateral (Soepomo, 1967: 94). Semua anak, baik laki-laki maupun perempuan wajib menanggung biaya pemakaman dan utang almarhum orang tua. Mereka juga setara haknya untuk mendapatkan besaran harta waris dari orang tua yang meninggal, tidak pandang jenis kelamin anak ataupun orang tuanya. Kemungkinannya hukum waris pada masyarakat Sunda Kuno juga demikian.

\section{SIMPULAN}

Fungsi peristilahan kekerabatan ialah menegaskan kedudukan individu di dalam jaringan hubungan konsanguinal dan afinal sehingga seseorang dapat mengetahui di dalam kategori apa ia berada dan menempatkan orang lain di dalam kategori tertentu yang dengannya dia berinteraksi. Pada gilirannya, istilahistilah kerabat yang terhubungan secara struktural ini menentukan perilaku yang diharapkan dari orang lain itu atau dari kita kepada mereka berdasarkan susunan hierarkis yang merentang dari tinggi ke rendah.

Berdasarkan paparan sepanjang tulisan ini, sistem kekerabatan Sunda Kuno dapat digolongkan ke dalam tipe lineal-Eskimo dengan ciri deskriptif untuk kerabat-kerabat di dalam keluarga ini dan cenderung klasifikatoris untuk kerabatkerabat di luar keluarga batih secara seimbang untuk kategori-kategori kerabat matrilateral ataupun patrilateral. Sistem peristilahan kekerabatan Sunda Kuno juga berwatak bilateral sehingga secara teoretis memengaruhi corak parental dari hukum keluarganya. Berdasarkan perbandingan, secara struktural tidak ada perubahan di dalam sistem peristilahan kekerabatan Sunda. 
Akhir kata, temuan dan simpulan yang diajukan di dalam tulisan ini haruslah dianggap sebagai informasi pendahuluan belaka tentang sistem kekerabatan Sunda Kuno karena kajian ini hanya menelusuri keterangan dari empat naskah kuno. Masih terbuka ruang perbandingan lebih lanjut dengan menggali kandungan naskah-naskah Sunda Kuno lainnya untuk mendapatkan gambaran utuh tentang bagaimana orang Sunda di masa silam mengorganisasi diri melalui pranata kekerabatan. Terkait hal ini, studistudi gabungan filologi, arkeologi, dan antropologi terhadap kandungan naskah kuno, prasasti, atau tinggalan arkeologis tampaknya diperlukan sehingga khazanah pengetahuan kita tentang rupa dan dinamika kehidupan masyarakat kuno dapat dikembangkan.

\section{DAFTAR PUSTAKA}

Abdurrahman. (2015). Sanghyang Siksa Kanda ng Karesian. Bogor: Pustaka Amma.

Atja. (1981). Sanghyang Siksakanda ng Karesian: Naskah Sunda Kuno tahun 1518 Masehi. Bandung: Proyek Pengembangan Permuseuman Jawa Barat.

Atja, \& Danasasmita, S. (1981a). AMANAT DARI GALUNGGUNG (Kropak 632 dari Kabuyutan Ciburuy, Bayongbong-Garut). Bandung: Proyek Pengembangan Permuseuman Jawa Barat.

Atja, \& Danasasmita, S. (1981b). Carita Parahyangan: Transliterasi, terjemahan, dan catatan. Bandung: Proyek Pengembangan Permuseuman Jawa Barat.

Berthe, L. (1965). Aînés et Cadets L'alliance et la hiérarchie chez les Baduj (Java Occidental). L'Homme, 5(3/4), 189-223.

Braun, F. (1988). Terms of Address: Problems of Patterns and Usage in Various Languages and Cultures. Berlin: Mouton de Gyuter.

Danasasmita, S., Ayatrohaedi, Wartini, T., Darsa, U. A. (1987). Sewaka Darma (Kropak 408), Sanghyang Siksakanda ng Karesian (Kropak 630), Amanat Galunggung (Kropak 632). Transkripsi dan Terjemahan. Bandung: Bagian Proyek Penelitian dan Pengkajian Kebudayaan Sunda, Direktorat Jenderal Kebudayaan, Departemen Pendidikan dan Kebudayaan.

Darsa, U. A., Ekadjati, E. S., \& Ruhimat, M. (2004). Darmajati, Naskah Lontar Kropak 423: Transliterasi, Rekonstruksi, Suntingan, dan Terjemahan Teks. Bandung: Universitas Padjadjaran.

Garna, J. K. (1987). Orang Baduy. Bangi: Penerbit Universiti Kebangsaan Malaysia.

Geertz, H. (1989). The Javanese Family: A Study of Kinship and Socialization. Illinois: Waveland Press.

Handy, E. S. C., \& Pukui, M. K. (1951). The Polynesian Family in Ka-u, Hawa'i: IV-the Kinship System. Journal of the Polynesian Society, 60(4), 187-222.

Horikoshi, H. (1976). A Traditional Leader in a Time of Change: The Kijaji and Ulama in West Java. University of Illinois at Urbana-Champaign, USA.

Iskandar, J. (1998). Swidden Cultivation as a Form of Cultural Identity: The Baduy case. University of Kent at Canterbury. 
London, G. (2000). Ethnoarchaeology and Interpretation. Near Eastern Archaeology, 63, 2-8.

Lowie, R. . (1928). A Note on Relationship Terminologies. American Anthropologist, 30, $263-$ 267.

Murdock, G. P. (1949). Social Structure. New York: The Macmillan Company.

Nastiti, T. S. (2006). Old Sundanese Community. In T. Simanjuntak, M. Hisyam, B. Prasetyo, \& T. S. Nastiti (Ed.), Archaeology: Indonesian Perspective (hal. 424-447). Jakarta: LIPI.

Nastiti, T. S. (2011). Early writings in Indonesia. In S. M. S. Chia \& B. W. Andaya (Ed.), Bujang Valley and Early Civilisations in Southeast Asia (hal. 295-310). Kualalumpur: Department of National Heritage, Ministry of Information, Communications and Culture.

Nastiti, T. S., \& Djafar, H. (2016). PRASASTI-PRASASTI DARI MASA HINDU BUDDHA (ABAD KE-12-16 MASEHI) DI KABUPATEN CIAMIS, JAWA BARAT. PURBAWIDYA: Jurnal Penelitian dan Pengembangan Arkeologi, 5(2), 101. https://doi. org/10.24164/pw.v5i2.115

Nastiti, T. S., \& Widyastuti, E. (2012). Analisis Pseudo Prasasti dari Sukabumi. PURBAWIDYA: Jurnal penelitian dan Pengembangan Arkeologi, 3(1), 77. https://doi.org/10.24164/ pw.v1i1.11

Pospisil, L., \& Laughlin, W. L. (1963). Kinship Terminology and Kindred among the Nunamiut Eskimo. Ethnology, 2(2), 180-189.

Riggs, J. (1862). A Dictionary of Sunda Language of Java. Batavia: Lange \& Co.

Robson, S. O. (1987). The Terminology of Javanese Kinship. Bijdragen tot de Taal-, Land- en Volkenkunde, 143(4), 507-518.

Schusky, E. L. (1965). Manual for Kinship Analysis. New York: Holt, Rinehart and Winston.

Soepomo. (1967). Hukum Perdata Adat Jawa Barat. Jakarta: Djambatan.

Surjaman, U. (1960). Tempat Pemakaian Istilah Klasifikasi Kekerabatan pada Orang Djawa dan Sunda dalam Susunan Masjarakat. Penerbit Universitas.

Suryani, E. (2001). Kamus Bahasa Naskah dan Prasasti Sunda Abad ke-11 s.d. ke-18. Bandung: Kerja sama Komunitas Pernaskahan Sunda Purbatisti dengan Pemerintah Kota Bandung.

Zoetmulder, P. J. (1995). Kamus Jawa Kuna Indonesia. Jakarta: Gramedia Pustaka Utama. 


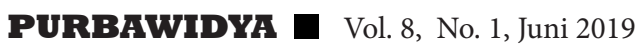

